\title{
Detection of Chlamydophila abortus in sheep by Polymerase
}

\section{Chain Reaction}

\author{
Wafaa A. Osman* \\ Animal Health Department, Desert Research Center, Cairo Egypt.
}

\begin{abstract}
This study was carried out on 180 pregnant ewes located at Ras Sedr research station desert research center, from 2003 to 2005. Twenty five cases of abortion were recorded and examined serologically by complement fixation test (CFT). $17(68 \%)$ out of these 25, showed positive results against Chlamydophila abortus and $3(15 \%)$ out of 20 apparently healthy pregnant ewes were serologically positive. Due to the fact that both clinical signs and pathological findings are not specific in case of chlamydial infection and also due to the fact that CFT is accompanied by false positive reactions due to cross reactivity between chlamydial species, five samples from serologically positive aborted dams were subjected to polymerase chain reaction (PCR). They revealed positive results for Chlamydophila abortus at $119 \mathrm{bp}$. Therefore, PCR is proven to be reliable, rapid and specific diagnostic technique in the diagnosis of chlamydial infection.
\end{abstract}

Chlamydiosis is a contagious disease infecting all livestock species, but sheep and goats are the most commonly affected (Storz, 1971 and Sharma et al. 1983). The classic symptoms of the disease are abortion, still birth or premature delivery of weak lambs. Aborted animals are subsequently immune and will usually not abort with a chlamydial infection again. The animal is still infected and can transmit the organism to other animals through the placenta and vaginal discharges (Shalaby et al., 1987; Coetzer et al., 1994; Asrani et al., 1996, Batta et al., 1997; Radostits et al., 2000 and Rekiki et al., 2002).

Chlamydophila abortus (Chlamydia psittaci) is widely distributed obligate intracellular pathogens, which exhibits a broad pathogenic potential (Fukushi and Hirai, 1992).

Animals frequently become infected, but show no signs and stress may predispose clinical disease either as sporadic cases or as epidemics. The feco-oral is the most common route of transmission. Also aerosol, contact and venereal transmission are possible. Chlamydiosis may result in abortion, still birth or weakness of lambs and kids (Storz, 1971; Sharma et al., 1983; Miller et al., 1990 and Chiocco et al.,

\footnotetext{
* Corresponding author. Tel.: +20 26369132; fax: +2026387808 .

E-mail address: wosman_vet@yahoo.com (Wafaa A. Osman).
}

1992).

Chlamydia psittaci was found to be responsible for $20 \%$ of ovine abortion reported annually in Great Britain (Aitken, 1986) constituting the most common cause of abortion in sheep (Aitken et al., 1990). Abortion in newly infected flock with enzootic abortion may be as high as $30 \%$, while the rate on flocks experiencing a reinfection is less than 5\% (Kendrick and Howarth, 1992). The late abortion and premature lambing are the only clinical manifestations of enzootic abortion. Retention of the fetal membranes may occur in some cases (Jubb et al.,1993). Chlamydia psittaci was isolated from the placenta of the aborted ewes. Moreover, serological studies showed that Chlamydia antibodies in ewes' sera in Egyptian farms were $11.68 \%$ using complement fixation test (CFT) (El-Sayed, 1993).

CFT is the most widely accepted serodiagnostic method for chlamydial infection in animals (Kaltenbook et al., 1997) as it gives satisfactory results with ovine, caprine and avian serum samples, but not with bovine samples (Butty and Nicolet, 1987).

Pathogenic changes were observed as subcutaneous petechial hemorrhages in the skin of legs, hips, neck and in the head of chlamydial aborted foeti (Studdert, 1968). The necrotic placentitis is the primary pathological lesion of chlamydial infection in sheep and goats (Aitken, 1989). 
Table (1): The master mix ingredients and primers concentration used in PCR.

\begin{tabular}{lcccc}
\hline \multicolumn{1}{c}{ Constituent } & $\begin{array}{c}\text { Initial } \\
\text { concentration }\end{array}$ & Amount $(\mu \mathrm{l})$ & $\begin{array}{c}\text { Final } \\
\text { concentration }\end{array}$ & $\mathbf{x}^{\mathbf{8}}$ \\
\hline Distilled water & & 13.2 & & $105.6 \mu \mathrm{l}$ \\
Buffer & $10 \mathrm{x}$ & 2.0 & & $16.0 \mu \mathrm{l}$ \\
dNTP & $10 \mathrm{mM}$ & 0.4 & $0.2 \mathrm{mM}$ & $3.2 \mu \mathrm{l}$ \\
Taq polymerase & $5 \mu / \mathrm{Ml}$ & 0.4 & $2 \mu / \mathrm{Ml}$ & $3.2 \mu \mathrm{l}$ \\
Primer 2AF & $20 \mathrm{mM}$ & 1.0 & $1 \mathrm{mM}$ & $8.0 \mu \mathrm{l}$ \\
Primer 2Br & $20 \mathrm{mM}$ & 1.0 & $1 \mathrm{mM}$ & $8.0 \mu \mathrm{l}$ \\
Total volume & & $18.0 \mu \mathrm{l}$ & & $144.0 \mu \mathrm{l}$ \\
\hline
\end{tabular}

Polymerase chain reaction (PCR) is one of the most modern advanced techniques used for accurate diagnosis of the causative agents (Creelan and McCullough, 2000; Amin, 2003). It has rapidly become one of the most widely used techniques in molecular biology. It was proven to be rapid, relatively inexpensive and simple means of producing relatively large numbers of copies of DNA molecules from minute quantities of DNA material.

The aim of this study was to investigate the presence of Chlamydial infection by PCR and serodiagnostic studies using complement fixation test. Histopathological changes were also studied.

\section{Materials and Methods}

Animals. This study was performed on total number of 180 pregnant ewes located in Ras Sedr Research Station (this station belonged to Desert Research Center). History and clinical examination of animals were recorded. Samples were collected during the period from 2003 to 2005

Serum samples. They were collected from aborted ewes (4 weeks post abortion) as well as from apparently healthy pregnant ewes for detection of chlamydial antibodies using complement fixation test.

Tissue samples. Tissue samples were collected from placenta of aborted ewes and internal organs of aborted foeti and newly born deaths (liver, kidneys, heart, brain, lungs and spleen) for gross examination and histopathological studies. The collected samples were fixed in $10 \%$ neutral buffered formalin. The fixed specimens were then washed, dehydrated and embedded in paraffin wax. The tissues were sectioned at $4-5 \mu$ thickness and stained with haematoxylin and eosin (H\&E) for histopathological examination and stained with Gemeniz stain as special stain for Chlamydia psittaci (Bancroft et al., 1996).
Antisera. Reference antisera for chlamydia (Chlamydia psittaci CFT reagents, " Seiken "), were obtained from Denka Seiken Co., Tokyo, Japan. Anti-sera were used for detection of chlamydial antibodies in the suspected materials. Reference Chlamydial antigen. Obtained from Denka Seiken Co., Tokyo, Japan. It was used in serological detection of antibodies.

Complement. Freeze dried preparation of preserved guinea pig serum (Welcome) was used in Complement Fixation Technique.

Polymerase Chain Reaction (PCR). From (5) serologically positive cases for chlamydiosis, tissue samples (placenta, internal organs of aborted foeti as liver, kidney, lung and brain) were subjected to PCR. Deparaffinizing the paraffin embedded samples then starts the process of DNA extraction.

DNA extraction. The genomic DNA was extracted from samples using Dneasy tissue kit purchased from QIA Gen, Basel, Switzerland according to (Venables et al., 1997).

PCR amplification of chlamydial DNA. It was performed on the extracted DNA from tissue samples using oligonucleotide primers Chla.2 AF:5-GCTTTTCTAATTTACACC-3 and Chla. 2 Br: 5- ATAGGGTTGAGACTATCCACT - 3 according to (Sykes et al., 1997). $2 \mu$ of template added to each tube and $2 \mu \mathrm{l}$ of distilled water added to tube of negative control (Table. 1). The reaction was subsequently run at $95^{\circ} \mathrm{C}$ for $10 \mathrm{~min}$. then for 40 cycles at $95^{\circ} \mathrm{C}$ for 30 seconds, $50^{\circ} \mathrm{C}$ for 30 seconds, and $72^{\circ} \mathrm{C}$ for 45 seconds, followed by an additional elongation at $72^{\circ} \mathrm{C}$ for 10 minutes. Reaction product was visualized by ethidium bromide staining under UV transillumination after electrophoresis on $1.5 \%$ agarose gel.

\section{Results}

History of farms. The rate of abortion in the first year (2003) was high in pregnant ewes, while the rate of abortion decreased year after year. 
Table (2): Results of CFT in aborted and apparently healthy pregnant ewes.

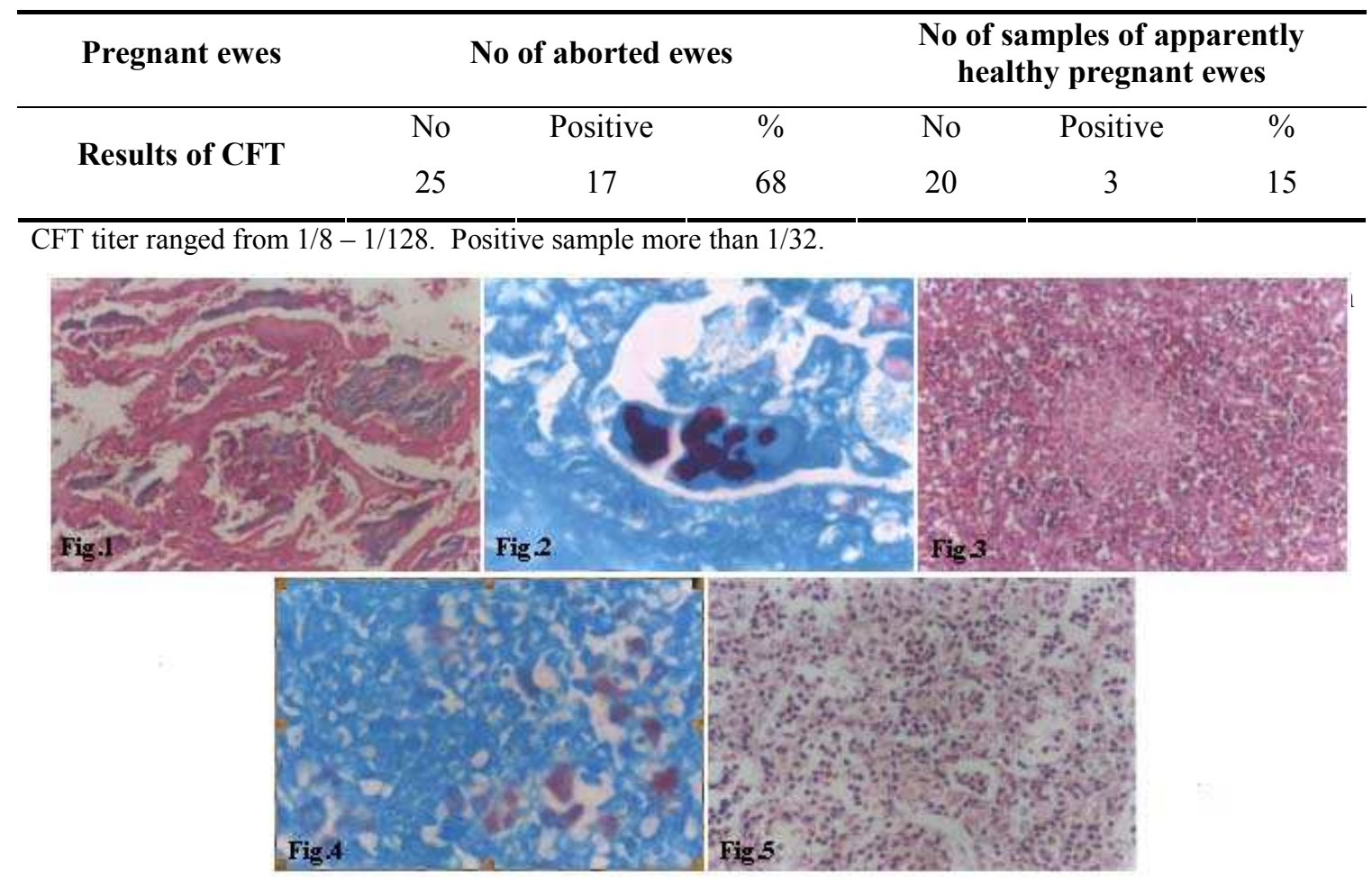

Fig. (1): Fetal placenta, showing severe extensive necrosis, myxomatosis degeneration of chorioallantoic villi and presence of inflammatory cells and cellular debris within the crypts (H \& E, $x$ 100).

Fig. (2): Fetal placenta, showing the presence of chlamydial elementary bodies within the trophoblast cells. (Gimenez stain, $x$ 1000).

Fig. (3): Liver of aborted foetus, showing focal area of hepatic cell necrosis associated with diffuse infiltration of lymphocytic cells ( $H \& E, x$ 100).

Fig. (4): Liver of aborted foetus, showing the presence of intracytoplasmic chlamydial elementary bodies as bright granules (Gimenez stain, $x$ 400).

Fig. (5): Lung of aborted foetus, showing aggregations of neutrophils and macrophages within the alveoli (H \& E, x 200).

Clinical manifestation. The most common clinical signs observed in pregnant ewes were abortion at late stage of pregnancy in the first year, while still birth or birth of weak unthrifty lambs were recorded in the second and third year more than abortion.

Serological studies. Results of serological studies were demonstrated in Table 2.

Histopathological findings:

Fetal placenta. There was severe necrosis of chorioallantoic villi with sloughing of the trophoblastic cells covering the villi into the Severe haemorrhages in the intercotyledonary areas were seen. Marked signs of vasculitis were noticed. Chlamydial elementary bodies were detected in the cytoplasm of trophoblsats as red

\section{Aborted fetal organs.}

Liver. It showed multiple foci of hepatic cell necrosis associated with diffuse infiltration of mononuclear cells aggregations mostly lymphocytes in hepatic parenchyma (Fig. 3). It appeared as bright red granules against blue back ground in section stained with Gimenez stain (Fig. 4).

Lung. It displayed aggregations of neutrophils and macrophages in the lumen of alveoli (Fig. 5). In addition, the alveolar walls were thickened, pulmonary blood vessels appeared dilated and congested.

Results of PCR. Five randomly collected 


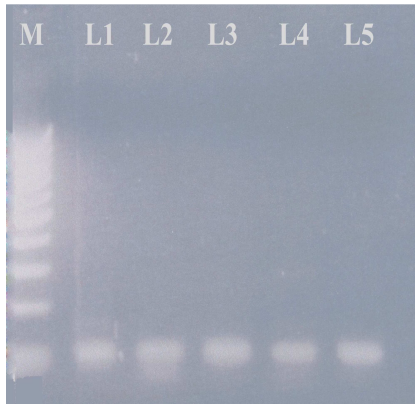

Fig. (6): PCR of (Chlamydiophila abortus) DNA from formalin-fixed and parafin embedded tissues of aborted ovine foeti. PCR products were separtaed on $1.5 \%$ agarose gel and stained with ethidium bromide $M, 100$ bp ladder marker; lane 1-5 specific C. psittaci PCR product (119 bp detected).

samples of placenta and aborted foeti of aborted ewes from serologically

positive cases for Chlamydophila abortus revealed positive results by using PCR (119 bp).

The positive control showed the excepted amplification product (119bp) as shown in Fig. (6).

\section{Discussion}

Ovine chlamydial abortions (ovine enzootic abortion) is an infectious and contagious disease clinically characterized by abortion and weak neonates. The etiological agent is Chlamydophila abortus (Chlamydia psittaci) which is considered one of the most common pathogens of small ruminants. Chlamydiosis is the principle cause of infertility in bovines as well as in small ruminants (Pugliese, 2001). It has important economic implications and represents a significant zoonotic risk. Clinical diagnosis is often difficult because the clinical and pathological lesions are not specific (Marsilio et al., 2005).

A definitive diagnosis is based on correlation between both clinical signs and pathological findings. The obtained results were identical to those described previously by (Eisa and Hamoda, 2002; Kendrick and Howarth, 1992).

Serological studies using complement fixation test is the most widely used serological test for detection of chlamydiosis. Positive results were detected in $17(68 \%)$ out of 25 of aborted cases and $3(15 \%)$ out of 20 of apparently healthy pregnant ewes. The detection of chlamydial antibodies in investigated samples by CFT was identical to that obtained by Schmatz et al. (1978); Martin (1995); Mousa et al. (1998); Joshi, (1998); Ozturic, et al. (1998); Vojinovic (1999) and Quinlan (1999).

CFT is sensitive test as it can diagnose Chlamydia psittaci in $20 \%$ of sera of aborted ewes (Duman and Durak, 1998).

Seroprevalence survey of chlamydiosis among cows and buffaloes using CFT, agar gel precipitation test and elementary body agglutination test resulted in positive percentages of $21.16 \%, 17.5 \%$ and $12.5 \%$, respectively and the CFT was the most sensitive test (Paul et al., 2002). In addition, Buendia et al. (2001) used CFT in diagnosis of Chlamydophila abortus in sera of sheep with $71 \%$ sensitivity and $83.6 \%$ specificity while Cislokova et al. (1999) diagnosed C. psittaci in small mammals by CFT with $16.9 \%$ positivity, it is concluded that small mammals play an important role in transmission C. psittaci.

On the other hnad, ELISA is more sensitive and specific than CFT and can detect chlamydial antibodies in sera of sheep (Borel et al., 2002; Henning and Sting, 2002) as CFT is complicated by false positive reaction resulting from cross reactive antibodies to Chlamydophila pecorum (Longbotton et al., 2001).

The main histopathological findings in the placenta and aborted foeti of aborted ewes due to chlamydiosis were development of necrosis and inflammatory changes in internal organs. These results were parallel with that of Buxton et al. (1990; 2002); Chanton et al. (2002) and Desouky et al. (2004). Such changes could be attributed to embolic dissemination of chlamydial infection from placenta (Buxton et al., 1990) as indicated by the presence of elementary bodies in the liver of aborted foeti. The initial interaction of Chlamydia with the host cells begins with the attachment of elementary bodies to the cells followed by phagocytosis within membrane limited vacuole called inclusion which don't fuse with lysosomes of cells and explain the survival of the organism in the intracellular environment (Escalante-Ochoa et al., 1998).

It is interesting to mention that clinical signs and pathological findings are not specific also, complement fixation test is complicated by false positive a fact that necessitate the use of another sensitive test like PCR in the diagnosis of chlamydiosis.

Five randomly collected tissue samples of placenta and aborted foeti, (serologically positive for $C$. psittaci) were subjected to PCR using $2 \mathrm{~A}$ and $2 \mathrm{~B}$ primers which are specific for 
identification of $C$. psittaci DNA. All the examined tissue samples showed the expected amplification product specific for $C$. psittaci (119 bp). These findings were in parallel with (Thiele et al. 1992; Creelan and McCullough 2000; Mi-Zu Huang et al., 2002; Amin 2003; Desouky et al., 2004) who reported that PCR is a specific, sensitive and rapid technique for detection of Chlamydophila abortus (C. psittaci) in ewes. Also with PCR it is possible to diagnose $C$. abortus from archival material with no culture examination. Furthermore, PCR is less labour consuming and the results can be obtained within a few hours.

\section{References}

Aitken, I. D. (1986): Chlamydial abortion in ewes. In practice, 8: 236-237.

Aitken, I. D. (1989): Animal Chlamydial abortion. Epidemiology. pp. 11-13.

Aitken, I. D.; Clarkson, M. J. and LinkLater, K. (1990): Enzootic abortion of ewes. Vet. Rec., 127: 136-138.

Amin, A. S. (2003): Application of touchdown enzyme time release (TETR)-PCR for diagnosis of chlamydophila abortus infection. Res. Vet. Sci., 74 (3): 213-217.

Asrani, R. K.; Batta, M. K.; Joshi, V. B. Katoch, R. C.; Sharma, M.; Sambyal, D. S.; Singh, S. P. and Nagal, K. B. (1996): Comparative pathology of naturally occurring chlamydial pneumonia among domestic animals in Hinachal pradesh. Ind. Vet. J., 73: 623-627.

Bancroft, J. D.; Stenvens, A. and Turner, D. R. (1996): Theory and practice of histological techniques $4^{\text {th }}$ ed., Churchill Livingstone, New York, Edinburgh, London, Melbourne. Sanfrancisco, Tokyo.

Batta, M. K.; Katoch, R. C.; Asrani, R. K.; Sharma, M.; Joshi, V. B. and Nagal, K. B. (1997): prevalence of chlamydial pneumonia among livestock in Himachol Pradesh. Ind. Vet. J., 74 (10): 824826.

Borel, N.; Doherr, M. G.; Vretou, E.; Psarrou, E.; Thoma, R. and Pospischil, A (2002): Ovine enzootic abortion: seroprevalence in Switzerland using a comparative enzyme linked immunosorbent assay (ELISA). SAT-Schweizer-Archiv-fur-Tierheilkunde, (144) 9: 474 482

Buendia, A. J.; Cuello, F., Rio-L-de, l.; Gallego, M. C.; Caro, Mr.; Samas, J. and del-Rio-L. (2001): Field evaluation of a new commercially available ELISA based on a recombinant antigen for diagnosing chlamydophila abortus (Chlamydia psittaci serotype 1) infection veterinary - Microbiol., (78) 3: 229-239.

Butty, F. B. and Nicolet, J. (1987): Chlamydiosis in Switzerland: Comparative study of diagnostic techniques. Schweizer Archivfur Tierheilkunde, 129 (1): 1-13.

Buxton, D.; Anderson, I. E.; Lougbottom, M.; Wattegedera S. and Entrican, G. (2002): Ovine chlamydial abortion: characterization of the inflammatory immune response in placental tissues. J. Comp. Pathol., 127(2-3): 133-141.

Buxton, D., Barlow, R. M.; Finlayson, J.; Anderson, I. E. and Mackellar, A. (1990): Observations on the pathogenesis of chlamydia psittaci infection in pregnant sheep. J. Comp. Pathol., 102: 221-237.

Chanton, Greutmann H.; Thoma, R.; Corboz, L.; Borel, N. and Pospischil, A. (2002): Abortion in small ruminants in Switzerland : investigations during two lambing seasons with special regard to Chlamydia. SAT-Schweizer-Archivfur-Tierheilkunde, 144 (9): 483-492.

Chiocco, D.; Troiano, P. and Cavaliene, N. (1992): Prevalence of chlamydiosis as a cause of abortion in sheep and goat farms in Puglia and Basilicata. Parxis Veterinaria Milano., 13 (3): 21-22.

Cislokova, L.; Stanko, M.; Peterkova, J.; Prokopcakova, H. and Pet-Ko, B. (1999): Chlamydia seroprevlance in small mammals from eastern Slovakia. Slovensky Veterinarsky Casopis, 24 (1): 43-47.

Coetzer, J. A. W., Thomson, G. R. and Tustin, R. C. (1994): Infectious diseases of livestock with special reference to South Africa. Cape Town Oxford New York. Oxford University press.

Creelan, J. L. and Mecullough, S. J. (2000): Evaluation of strain-specific primer sequences from an abortifacient strain of ovine Chlamydophila abortus (Chlamydia psittaci) for the detection of EAE by PCR. FEMS-Microbiol. Lett., 190 (1): 103-108.

Desouky, H. M.; Abd-EI Razik, K. A. and Ahmed, Y. F. (2004): Diagnostic studies on ovine chlamydial abortion. J. Appl. Vet. Sci., NRC. 1: (in press).

Duman, R. and Durak, Y. (1998): Investigations on Chlamydia psittaci infections causing abortion in sheep in Kenya district using the complement fixation test. TurkVeterinerlik-ve-Hayvancilik-Dergisi., 22 (6): 511-515.

Eisa, M. I. and Hamoda, F. K. (2002): Investigations on problem of chlamydiosis among domestic and wild sheep. Assiut Vet.Med. J., 48 (95): 76-90.

El-Sayed, A. S. A. (1993): Studies on chlamydiosis in farm animals. Ph. Thesis (Infectious diseases). Fac. Vet. Med., Cairo Univ.,Egypt.

EsCalante-Ochoa, C.; Ducatell, R. and Haesebrouck, F. (1998): The intracellular life of Chlamydia psittaci: how do the bacteria interact with the host cell ? FEMS Microbiol. Rev., 22: 65-78.

Fukushi, H. and Hirai, K. (1992): Proposal of Chlamydia pecorum sp. Nov. for chlamydia strains derived from ruminants. Int. J. Syst. Bacteriol., 42: 306-308.

Henning, $K$ and Sting, R. (2002): Evaluation of an enzyme linked immunosorbent assay (ELISA) for the detection of anti-chlamydial antibodies in ovine sera. Tieraztliche-umschau, 57 (12): 676-683.

Joshi, V. B.; Katoch, R. C.; Nagal, K. B.; Batta, M. K.; Madhuneet, S. and Singh, M. (1998): Seroprevalence of Chlamydia psittaci among yaks and equines in Himachal Pradesh. J. App. Anim. Res., 14 (2): 171-174.

Jubb, K.V.; Kennedy, P.C. and Palmer, N. (1993): Pathology of domestic Animals. $3^{\text {rd }}$ ed. Academic press. Inc., New York, London.

Kaltenbook, B.; Heard, D.; DeGraves, F.J. and Schmeer, N. (1997): Use of synthetic antigens improves detection by enzyme linked immunosorbent assay of antibodies against abortigenic Chlamydia psittaci in ruminants. J. Clinic. Microbiol., 35 (9): 2293-2298.

Kendrick, J. W. and Howarth, J. A. (1992): Reproductive infections. In the : Reproduction in farm animals, By Hafez., $6^{\text {th }}$ ed., Lea and Febiger, Philadelphia, USA, pp. 394.

Longbotton, D.; Psarrou, E.; Livingstone, M. and Vretou, E. (2001): Diagnosis of ovine enzootic abortion using an indirect ELISA (roM pg1B iELISA) based on a recombinant protein fragment of the polymorphic outer membrane protein PoMpg1B of Chlamydia abortus. FEMS-Microbiol. $\quad$ Lett., $195 \quad$ (2): 157-161. 
Marsilio, F.; Di Martino, B.; Di Francesco, C. E. and Marsilio Meridiani, M. I. (2005): Diagnosis of ovine chlamydial abortions by PCR-RFLP performed on vaginal swabs. Vet. Res. Comm., 29 (1): 99-106.

Martin, P. K. (1995): A complement fixation, enzymelinked immunosorbent assay as an aid in the serological investigation of enzootic abortion in ewes. Res.Vet.Sci., 58 (2): 193-194.

Miller, M. A.; Turk, J. R.; Nelson, S. L.; Lek, A. P.; Solor Zano, R.; Fales, W. H.; Morehouse, L. G.; Gosser, H. S. and Vander, L. (1990): Chlamydial infections in aborted and stillborn lambs. Vet. Med. Diag. Invest., 2 (1): $55-58$.

Mi-ZuHuang, Qin-ling.; Mi-ZH. Qin-L (2002): Study on detection methods of Chlamydia psittaci by nested PCR and DNA sequencing analysis. Chin. J. Zoon., 18 (3) 68-70.

Moussa, H. A. A.; Nariman, A. Rahmy and Nagwa, A. Said (1998): Serological, immunological and pathological investigation on Chlamydia psittaci problem in sheep. Egypt. J. comp. Path Clin. Pathol., 11 (2): 125-141.

Nabeya, M.; Kaneko, K.; Ogino, H.; Nakabayashi, D.; Watanabe, T.; Murayama, J.; Hayashr, K.; Fukushi, H.; Yamaguchi, T.; Hireu, K.; Inaba, Y. and Matumoto M. (1991): Abortion in Japanese cows caused by Chlamydia psittaci. Vet. Microbiol., 29: 3-4.

Ozturk, M.; Nadas, M.G. and Turutogh, H. (1998): Prevalence of Chlamydia psittaci infection in ewes in Istanbul. Pendik-Veteriner-Microbiyoloji-Dergisi, 29 (1-2): 73-81.

Paul, R.; Katoch, R. C.; Rajesh, Chahota.; ArvindMahajan.; Chahota, R. and Mahajan, A. (2002): seroprevalence of chlamydiosis among cows and buffaloes in Hinachal Pradesh. Ind. J. Anim. Sci., 72 (6) 434-435.

Pugliese, A.; Pietro, di.; Britti, D.; Giudice, E.; Niutta, P.P. and Di-Pietro, S. (2001): Investigation into the spread of Chlamydia psittaci infection in cattle reared in the province of Agrigento. Emergenza BSE., il ruolo del buiatra nella filiera alimentare: il bovino dall, allevamentoalla Tavola. Congressonazionale alghero 11-13 maggio, Italy. Atti-della-Societa-Italiana-di-Buiatria. 33: 319-325.

Quinlan, J. F. and Mc Guckin, P. K. (1999): Chlamydial abortion in a sheep flock: a case report. Irish Vet. J., 52
(12): 668-670.

Radostits, O. M.; Gay, C. C .; Blood, D. C. and

Hinchcliff, K.W. (2000): Veterinary medicine a text book of the diseases of cattle, sheep, pigs, goats and horses, $9^{\text {th }}$ ed. W.B. Saunders Company LTd.

Rekiki, A.; Sidi-Boumedine, K.; Souriau, A.; Jemli, J.; Hammami, S. and Rodolakis, A. (2002): Isolation and characterization of local strains of Chlamydia abortus (Chlamydia psittaci serotype 1) from Tunisia. Vet. Res., 33 (2): 215-222.

Schmatz, H. D.; Krausis, H.; Vientel, P.; Ismail, A. S. and Hussien, A. A. (1978): Serological survey of Rickettsia and Chlamydial antibodies in domestic ruminants in Egypt, Somalia and Jordan, Acta. Tropic., 35: 101-111.

Shalaby, M. A., Hasanein, M. M. and Fayed, A. A. (1987): Studies on Chlamydia infection among sheep in the kingdom of Saudi Arabia. J. Vet. Med. Assoc., 47 (1-2): 195-201.

Sharma, K. N., Mehrotra, P. K. and Methrotra, P. N. (1983): Chlamydial infections in sheep : pneumonitis and abortions, Indian J. Comp. Microbiol. Immunol Infec. Dis., 4 (3): 145-148.

Storz, J. (1971): Chlamydia and Chlamydia-induced diseases Chales. C. Thomas., Springfield, I 11 inosis, USA.

Studdert, M.J. (1968): Bedsonia abortion of sheep II. Pathology and pathogenesis with observation on normal ovine placenta. Res. Vet. Sci., 9: 57-64.s

Sykes, J. E.; Studdert, V. P. and Anderson, G. (1997): Comparison of Chlamydia psittaci from cats with upper respiratory tract disease by polymerase chain reaction analysis of the ompA gene. Vet. Rec., 140: 310-313.

Thiele, D.; Wittenbrink, M. M.; Fischer, D. and Krauss, H. (1992): Evaluation of the polymerase chain reaction (PCR) for detection of Chlamydia psittaci in abortion material from ewes. Zbl. Bakt., 277: 446-453.

Venables, C.; Lysons, R.; Horigan, M.; Staggy, D. and Dawson, M. (1997): Bovine immunodeficiency - like virus : inactivation in milk by pasteurization. Vet. Rec., 140: 275. Vojinovic, D. (1999): Investigation of infections with Chlamydia psittaci var ovis in sheep herds in eastern serbiaVeterinarski-Giasnik., 53 (3-4): 173-180.

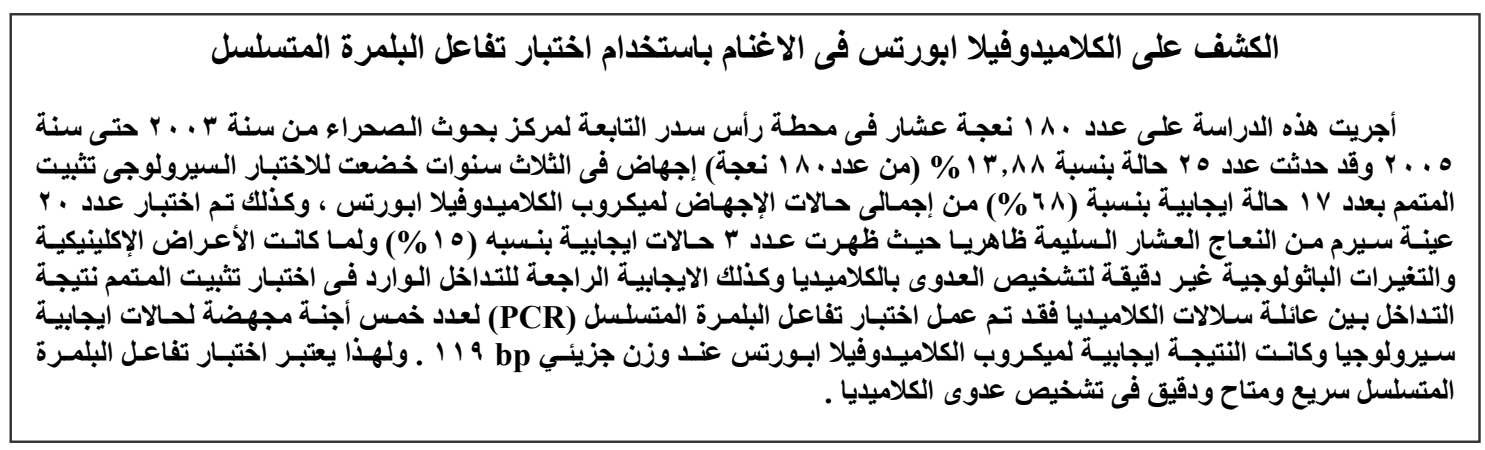

